\title{
Molecular characterization of field resistance to Fusarium head blight in two US soft red winter wheat cultivars
}

\author{
Shuyu Liu • Carl A. Griffey • Marla D. Hall • Anne L. McKendry • \\ Jianli Chen · Wynse S. Brooks · Gina Brown-Guedira • \\ David Van Sanford $\cdot$ David G. Schmale
}

Received: 4 December 2011 / Accepted: 18 June 2013 / Published online: 6 July 2013

(C) The Author(s) 2013. This article is published with open access at Springerlink.com

\begin{abstract}
In the soft red winter wheat (Triticum aestivum L.) regions of the US, Fusarium head blight (FHB, caused by Fusarium spp.) resistance derived from locally adapted germplasm has been used predominantly. Two soft red winter wheat cultivars, Massey and Ernie, have moderate resistance to FHB. Mapping populations derived from Becker/Massey (B/M) and Ernie/MO 94-317 (E/MO) were evaluated for FHB resistance and other traits in multiple environments. Eight QTL in B/M and five QTL in E/MO were associated with FHB variables including incidence,
\end{abstract}

Communicated by D. Mather.

Electronic supplementary material The online version of this article (doi:10.1007/s00122-013-2149-y) contains supplementary material, which is available to authorized users.

S. Liu $(\bowtie) \cdot$ C. A. Griffey $(\bowtie) \cdot$ M. D. Hall $\cdot$ J. Chen .

W. S. Brooks

Department of Crop and Soil Environmental Sciences,

Virginia Tech, Blacksburg, VA 24060, USA

e-mail: SLiu@ag.tamu.edu

C. A. Griffey

e-mail: CGriffey@vt.edu

Present Address:

S. Liu

Texas A\&M AgriLife Research and Extension Center,

Texas A\&M University System, 6500 Amarillo Blvd W.,

Amarillo, TX 79106, USA

Present Address:

M. D. Hall

Limagrain Cereal Seeds, 6414 N. Sheridan, Wichita,

KS 67204, USA

A. L. McKendry

Department of Plant Science, University of Missouri,

Columbia, MO 65201, USA severity (SEV), index (IND), Fusarium damaged kernels (FDK), deoxynivalenol (DON), and morphological traits flowering time and plant height. Four QTL were common to both populations. Three of them were located at or near known genes: Ppd-Dl on chromosome 2DS, Rht$B 1$ on 4BS, and Rht-DI on 4DS. Alleles for dwarf plant height (Rht-Blb and Rht-Dlb) and photoperiod insensitivity $(P p d-D l a)$ had pleiotropic effects in reducing height and increasing FHB susceptibility. The other QTL detected for FHB variables were on 3BL in both populations, 1AS, $1 \mathrm{DS}, 2 \mathrm{BL}$, and $4 \mathrm{DL}$ in $\mathrm{B} / \mathrm{M}$, and $5 \mathrm{AL}(\mathrm{Bl})$ and $6 \mathrm{AL}$ in $\mathrm{E} /$ MO. The additive effects of FHB variables ranged from $0.4 \mathrm{mg} \mathrm{kg}^{-1}$ of DON to $6.2 \%$ for greenhouse (GH) SEV in $\mathrm{B} / \mathrm{M}$ and ranged from $0.3 \mathrm{mg} \mathrm{kg} \mathrm{mg}^{-1}$ of DON to $8.3 \%$ for GH SEV in E/MO. The 4DS QTL had epistasis with

Present Address:

J. Chen

Department of Agronomy, University of Idaho Aberdeen

Research and Extension Center, Aberdeen,

ID 83210, USA

G. Brown-Guedira

Eastern Regional Small Grains Genotyping Lab,

USDA-ARS, Raleigh, NC 27695, USA

D. Van Sanford

Department of Plant and Soil Sciences,

University of Kentucky, Lexington, KY 40546, USA

D. G. Schmale

Department of Plant Pathology, Physiology

and Weed Science, Virginia Tech, Blacksburg,

VA 24060, USA 
Ppd-D1, Qdon.umc-6AL, and Qht.umc-4BS, and additive $\times$ additive $\times$ environment interactions with the 4BS QTL for SEV, IND, and FDK in E/MO. Marker-assisted selection might be used to enhance FHB resistance through selection of favorable alleles of significant QTL, taking into account genotypes at Rht-Blb, Rht-Dla and Ppd-Dla.

\section{Introduction}

Fusarium head blight (FHB), mainly caused by Fusarium graminearum Schwabe [teleomorph: Gibberella zeae Schw. (Petch)], is a serious disease that reduces grain yield and quality of wheat (Triticum aestivum L.) in warm and humid areas worldwide. Growing resistant cultivars is an economically effective and environmentally sound way of managing FHB (Martin and Johnston 1982). Many QTL have been identified in diverse wheat sources worldwide (Buerstmayr et al. 2009; Liu et al. 2009; Loffler et al. 2009). Most resistant sources characterized to date are spring wheat genotypes from Asia and South America. Among winter wheat sources for which resistance QTL have been mapped, most are of European descent [e.g., Sincron and F201R from Romania (Ittu et al. 2000; Shen et al. 2003), Renan from France (Gervais et al. 2003), and Dream, Ritmo, and GS16-92 from Germany (Schmolke et al. 2005; Klahr et al. 2007; Schmolke et al. 2008)]; however, they are not adapted to most of the winter wheat production areas of the US. Currently, only a few soft red winter (SRW) wheat sources from the US including Ernie, Goldfield, Freedom, IL 94-1653, and VA00W-38 (Liu et al. 2005, 2007; Abate et al. 2008; Gilsinger et al. 2005; Gupta et al. 2001; Bonin and Kolb 2009; Liu et al. 2012b) have been genetically characterized for FHB resistance either in greenhouse or field conditions.

Screening for type II resistance (pathogen spread within the spike) under controlled environmental conditions via point inoculation is most reliable for assessing FHB severity (Bai and Shaner 1994). Therefore, many QTL mapping studies have been conducted as greenhouse experiments (Buerstmayr et al. 2009; Liu et al. 2009). However, assessment of FHB resistance expressed under field conditions is more comprehensive and provides information on the different types and overall level of FHB resistance. Many FHB field experiments have been conducted using grain spawn and/or conidia (asexual spores) spray inoculations in mist-irrigated nurseries (Buerstmayr et al. 2009; Liu et al. 2012b). Assessments made in these studies have included FHB incidence (INC) and severity (SEV) with subsequent analysis of FHB index (IND), Fusarium damaged kernels (FDK), and concentrations of deoxynivalenol (DON).

Plant height, heading date, flowering time, and the presence of awns have been reported to be associated with FHB. Previous studies have reported that tightly linked genes or pleiotropic effects of dwarfing genes rather than plant height per se confer increased FHB susceptibility in European wheat cultivars (Draeger et al. 2007; Srinivasachary et al. 2008). FHB resistance QTL were identified overlapping QTL for plant height and flowering time in wheat cultivars Renan and Recital (Gervais et al. 2003). Mesterhazy (1995) reported that wheat lines having long awns were more susceptible to FHB under natural conditions.

The process of identifying and characterizing new sources of FHB resistance in adapted germplasm and developing reliable markers to facilitate marker-assisted selection (MAS) and pyramiding of diverse resistance QTL is critical to the enhancement of FHB resistance in breeding programs. After more than a decade of FHB research on plant introductions, wheat breeders in the SRW wheat region of the US consider the use of FHB resistance from locally adapted sources to be most promising. SRW wheat cultivars with moderate resistance to FHB include Freedom, Ernie, Truman, Bess, Roane, Tribute, and Jamestown (Gooding et al. 1997; McKendry et al. 1995, 2005, 2007; Griffey et al. 2001, 2005, 2010). The current study used recombinant inbred lines (RILs) derived from two moderately FHB-resistant cultivars, Massey and Ernie, in the SRW wheat regions of the US with the following objectives: (1) map QTL associated with FHB resistance in Massey and Ernie using phenotypic data from multiple environments; (2) elucidate the main and epistatic effects of QTL and interactions between QTL and environments and; (3) determine the association between FHB resistance QTL with genes governing plant height, photoperiod sensitivity and awns, and their impact on breeding for FHB resistance.

\section{Materials and methods}

\section{Plant materials}

Massey $(R h t-B 1 b)$ was derived from the cross of Blueboy/Knox62 (Starling et al. 1984). Its semi-dwarf allele was derived from line Norin 10 (Murphy 1967). Becker, released by Ohio State University in 1985 (Lafever 1988), was derived from the cross of Hart/VA 66-54-10 (CItr 15293) and has Rht-Dlb and Rht8c, which is in coupling linkage with the 192 bp allele of Xgwm261. Massey is sensitive to photoperiod (Ppd-DIb) while Becker is insensitive (Ppd-Dla). The initial cross of Becker/Massey was made in 1991. Lines were advanced in bulk to the $F_{7: 14}$ generation by 2007 . Only 152 of the initial RILs were used in FHB tests in the greenhouse for severity in 2007 and 2008 and in the field FHB nursery in 2008 and 2009 due to heterogeneity of some lines (Liu et al. 2012a).

The wheat cultivar Ernie $(R h t-B 1 b)$ has partial resistance to FHB while MO 94-317 (Rht-DIb) is susceptible 
(McKendry et al. 1995; Liu et al. 2005, 2007; Abate et al. 2008). Ernie is photoperiod sensitive $(P p d-D l b)$ and has the awn suppression gene B1. A set of 231 Ernie/MO 94-317 $\mathrm{F}_{11}$ RILs were advanced and evaluated in this study.

\section{Phenotypic screening and data analyses}

Parents and RILs of both populations were screened for FHB in multiple environments (Liu et al. 2012a). Eight environments were inoculated and mist-irrigated in the Virginia scab nurseries (VASN) at Blacksburg in 2007 (B/M) and from 2008 to 2009 (B/M, E/MO), Missouri scab nursery (MOSN) at Columbia in 2008 (B/M, E/MO), Virginia greenhouse (VAGH) in 2007 and $2008(\mathrm{~B} / \mathrm{M})$, and greenhouse at Columbia, MO in 2002 and 2003 for E/ MO reported by Liu et al. (2007) and Abate et al. (2008). Experiments were also conducted under natural field conditions at Lexington, Kentucky (KYFLD) in 2008 (B/M) and at Warsaw, Virginia (VAFLD) in 2009 (B/M, E/MO). Single $1.2 \mathrm{~m}$ head rows with $0.3 \mathrm{~m}$ spacing between rows were planted in randomized complete block designs with two replications for all tests except the VAFLD test having one replication of two head rows. Greenhouse experiments were arranged in randomized complete block designs with parents and RILs planted in D40 Deepots (Hummert International, Earth City, MO, USA) and evaluated according to the procedures described in Liu et al. (2007). The most aggressive $F$. graminearum isolates from $\mathrm{VA}$ and $\mathrm{MO}$, respectively, were used for spray inoculations $\left(1 \times 10^{4}\right.$ conidia spores per $\mathrm{mL}$ ) in the field FHB nurseries at flowering time and for point inoculations $\left(5 \times 10^{4}\right.$ conidia spores per $\mathrm{mL}$ ) of middle florets in greenhouse experiments. In field experiments, data for FHB variables including INC, SEV, IND, FDK and DON were collected following methods of Liu et al. (2012a, b). The data collected from greenhouse followed the procedure by Liu et al. (2007). The concentration of DON was measured using gas chromatography-mass spectrometry following procedures established by Khatibi et al. (2012) and Tacke and Casper (1996). In this study, assessments used to quantify FHB resistance including INC, SEV, IND, FDK, and DON are collectively referred to as FHB variables. Flowering time (FT, days from Jan 1 to $50 \%$ flowering) or heading date, INC, SEV, and IND were assessed in all six field environments except that SEV and IND were not assessed at KYFLD in 2008. FDK and DON were only estimated at VASN in 2008 and 2009 and at VAFLD in 2009. Plant height was recorded in the VASN and VAFLD tests in 2009 and the greenhouse experiment in 2010 as described by Liu et al. (2012a).

Analyses of variance (ANOVA) were conducted in all replicated experiments using PROC GLM (SAS Institute 2008). Correlation coefficients among FHB variables and other traits were calculated for each environment in VASN in 2008 and 2009 and VAFLD in 2009 using SAS PROC CORR.

Genotypic data

Sample DNA from each parent and RIL of B/M were extracted according to the protocol recommended at http:// www.triticarte.com.au/content/DNA-preparation.html and sent to Triticarte Pty Ltd (Yarralumla, Australia) for whole genome Diversity Arrays Technology (DArT) analysis (Akbari et al. 2006). A total of 740 DArT markers were scored. A set of 199 simple sequence repeat (SSR) markers were screened for polymorphism between the parents and 96 SSR markers were used to screen all RILs.

For E/MO RILs, in addition to 94 SSR loci and 45 amplified fragment length polymorphic markers mapped previously (Liu et al. 2007), 120 new SSR markers were tested for polymorphism and a set of 70 additional SSR were added to construct the new chromosome maps.

Primer sequences from GrainGenes 2.0 (http:// wheat.pw.usda.gov/GG2/index.shtml, Accessed 1 June 2010) were obtained either as synthesized directly labeled primers with fluorophores (FAM, NED, PET, or VIC) from Applied Biosystems (Carlsbad, CA, USA) or indirectly labeled with a $\mathrm{M}_{13}$ tail. Indirectly labeled primers were ordered from Integrated DNA Technology (Coralville, IA, USA). The PCR reaction solution preparation and amplification cycle were same as described by Christopher et al. (2013). The mixed solution of $2 \mu \mathrm{L}$ PCR product, $8.5 \mu \mathrm{L}$ of formamide containing 1/66 volume of GeneScan ${ }^{\mathrm{TM}} 500$ Liz $^{\circledR}$ Size Standard from Applied Biosystems (Carlsbad, CA, USA) was visualized via capillary electrophoresis on an ABI 3130xl Genetic Analyzer from Applied Biosystems (Carlsbad, CA, USA). GeneMarker from SoftGenetics, LLC (State College, PA, USA) was used to analyze polymorphic bands across the whole RIL population.

Construction of genetic map and detection of QTL

Molecular markers were analyzed using Joinmap 3.0 (Van Ooijen and Voorrips 2001) combined with MapMaker 3.0 (Lander et al. 1987) with logarithm of odds (LOD) at 3.0, genetic distance $<40 \mathrm{cM}$, and the Kosambi mapping function (Kosambi 1944). The generated map file and raw data file including markers and phenotypic data were imported into QTL Cartographer 2.0 (Wang et al. 2010) to generate files for further analyses.

QTL Network 2.0 was used to analyze the main additive $(\mathrm{A})$, epistatic effects $(\mathrm{A} \times \mathrm{A})$ and interaction effects of QTL and environments $(\mathrm{A} \times \mathrm{E}, \mathrm{A} \times \mathrm{A} \times \mathrm{E})$ (Yang et al. 2008) across all the tested environments. Each of eight traits (INC, SEV, IND, FDK, DON, GHSEV, FT, and HT) was assessed in between two and six environments for $\mathrm{B} / \mathrm{M}$ and from between 
two and four environments for E/MO. A 1,000 permutation test was used to calculate critical $F$-values for an experimentwise significance level of 0.05 . Tests to detect QTL were conducted at 1-cM intervals with a window size of $10 \mathrm{cM}$ (Yang et al. 2008). A Monte Carlo Markov Chain approach was used to estimate QTL effects. The genetic maps and QTL intervals were drawn using MapChart 2.0 (Voorrips 2002).

Group means with various combinations of alleles were analyzed for FHB variables and traits using Tukey's studentized range (HSD) of multiple comparisons with different sample sizes by SAS PROC GLM at $P<0.05$.

\section{Results}

Analysis of FHB variables and traits

Analyses of variance were conducted on data from tests with two replications for FHB variables and morphological traits in the VASN in 2008 and 2009 (Supplementary Table S1). RILs varied significantly $(P<0.001)$ for all FHB variables and traits (INC, SEV, IND, FDK, DON, FT, and HT) with the exception of DON in B/M. Year effects were not significant for SEV and FDK in B/M or for DON in both populations. The interactions between line and year were all significant at $P<0.001$ except for DON in $\mathrm{B} / \mathrm{M}$ and FT in E/MO. The results indicated that environmental effects significantly influenced FHB in addition to the major genetic effects.

Parental means and ranges among RILs for five FHB variables and three agronomic traits were analyzed using data from four environments (MOSN in 2008, VASN in 2008 and 2009, VAFLD in 2009) for B/M (Liu et al. 2012a) and E/MO (Data not shown). Transgressive segregants were identified among RILs for all FHB variables except for FHB INC in the MOSN in 2008 due to very high disease pressure (55-100 \% INC). Plants inoculated in FHB nurseries, VASN and MOSN, had high infection levels with maximum incidence, severity, or both up to $100 \%$.

Correlation coefficients of data from three environments including VASN in 2008 and 2009 and VAFLD in 2009 indicated that FHB variables including INC, SEV, IND, and FDK were significantly correlated with each other in both populations except for FDK with SEV in B/M and for SEV with IND in E/MO in 2009 VAFLD (Supplementary Table S2). Grain DON concentration was correlated with INC and FDK in all three environments for both populations except for DON with FDK in B/M in 2009 VAFLD. Plant height was negatively correlated with these five FHB variables in B/M except for DON in the VASN and VAFLD in 2009. Plant height of E/MO RILs was correlated with all five FHB variables in the 2009 VASN, while it was only correlated with INC and FDK in the 2009 VAFLD test. Flowering time was least correlated with other traits, particularly in the $\mathrm{B} / \mathrm{M}$ population.
Genetic mapping analysis

For B/M RILs, 589 DArT markers and 71 SSR markers were used to construct the genetic maps. A total of 468 DArT markers including seven from rye (Secale cereale), 28 from triticale ( $\times$ Triticosecale), 433 from wheat, and 54 SSR markers were mapped onto chromosomes. They covered all chromosomes except for 3D and 6D. The total genome coverage is 848.6 with $1.6 \mathrm{cM}$ per marker. However, some chromosomes were not covered very well, including chromosomes 1D, 2D, 4D, 5A, 5D, 6A, and 7D. For E/MO, 39 of the 71 new markers were mapped onto chromosomes 2BS, 2D, 3BL, 4BS, 4DS, and 5A in addition to those on maps published by Liu et al. (2007).

Significant QTL additive effects and their interaction with environments

Just as interactions between line and year were significant for FHB variables, so were the QTL by environment interactions. The main effects of QTL and QTL by environment interactions were estimated by additive (A) and additive by environment $(\mathrm{A} \times \mathrm{E})$, respectively, in both populations using combined analyses of data across corresponding environments (Table 1).

In B/M, ten QTL were associated with GHSEV, INC, SEV, IND, FDK, DON, FT, and HT (Table 1). Among the eight QTL associated with FHB variables, six had favorable effects derived from Massey (positive effects), while only the 4BS and 2BL QTL had favorable effects from Becker. The Becker allele of the 4BS QTL decreased INC, IND, and FDK while the $2 \mathrm{BL}$ QTL only decreased IND. The QTL Qfhs.vt-2DS had a significant additive effect on INC in six environments, which is estimated to be at the same position as $P p d-D 1$, at which Massey carries the allele for photoperiod sensitivity (Ppd-D1b). Two QTL on chromosomes 1DS and 3BL decreased GH SEV while the 1AS QTL decreased IND. The 4DS QTL, with the peak close to Rht-Dlb, reduced IND. Another QTL on chromosome 4DL, $34.5 \mathrm{cM}$ away from $R t h-D 1 b$, reduced DON and FT. Two QTL on chromosomes 7A and 2DS decreased HT. None of the $\mathrm{A} \times \mathrm{E}$ interactions were significant for QTL associated with FT or HT, while all the QTL for FHB variables had significant A $\times$ E interactions except for $Q f h s . v t$ $I A S$ on IND. The main additive effect of $Q f h s . v t-6 B L$ was not significant.

In E/MO, seven QTL associated with INC, SEV, IND, FDK, DON, FT and HT were identified based on field data from two to four environments in E/MO (Table 1) in addition to the 3BL and 4BS QTL based on GH SEV, FDK, and DON published previously (Liu et al. 2007; Abate et al. 2008). At all QTL, the favorable alleles decreasing FHB variables were from Ernie except the QTL on chromosome 
Table 1 The QTL additive effects and additive by environment interactions for Fusarium head blight variables and other traits of recombinant inbred wheat lines of Becker/Massey and Ernie/MO 94-317 based on data from eight environments in Virginia, Missouri, and Kentucky from 2007 to 2010

\begin{tabular}{|c|c|c|c|c|c|}
\hline $\begin{array}{l}\text { FHB variables } \\
\text { and traits }{ }^{\mathrm{a}}\end{array}$ & $\mathrm{QTL}^{\mathrm{b}}$ & Marker interval & $\begin{array}{l}\text { Peak position } \\
(\mathrm{cM})\end{array}$ & Additive $^{c}$ & $\begin{array}{l}\text { Additive } \times \\
\text { environment }^{\mathrm{d}}\end{array}$ \\
\hline \multicolumn{6}{|l|}{$\mathrm{B} / \mathrm{M}$} \\
\hline \multirow[t]{2}{*}{$\operatorname{INC}(6)$} & Qfhs.vt-2DS & Ppd-D1-Rht8 & 0.0 & 1.7 & $\begin{array}{l}-4.0 \text { (VASN 2008), } 6.3 \\
\text { (KYFLD 2008) }\end{array}$ \\
\hline & Qfhs.vt-4BS & Rht-B1-wPt1708 & 0.0 & -1.4 & -4.6 (VASN 2008) \\
\hline \multirow[t]{2}{*}{ GHSEV (2) } & Qfhs.vt-1DS & wPt1595-wPt7946 (1DS-5) & 0.8 & 3.1 & $\begin{array}{l}-3.1 \text { (VAGH 2007), } 3.0 \\
\text { (VAGH 2008) }\end{array}$ \\
\hline & Qfhs.vt-3BL & wPt4048-Xbarc164 & 24.9 & 6.2 & $\begin{array}{l}-5.4 \text { (VAGH 2007), } 5.4 \\
\text { (VAGH 2008) }\end{array}$ \\
\hline \multirow[t]{5}{*}{ IND (5) } & Qfhs.vt-1AS & wPt4735-wPt3870 (1AS-3) & 36.5 & 1.3 & $\mathrm{~ns}^{\mathrm{f}}$ \\
\hline & Qfhs.vt-2BL(2BL-6) & wPt0628-wPt2528 & 0.9 & -0.8 & $\begin{array}{l}\text { 1.6 (VASN 2008), }-2.2 \\
\quad(\text { MOSN 2008) }\end{array}$ \\
\hline & Qfhs.vt-4BS & tPt0602-wPt3908 & 12.2 & -1.1 & $\begin{array}{l}-2.0(\text { VASN2008), } 1.3 \\
\quad \text { (VASN 2007) }\end{array}$ \\
\hline & Qfhs.vt-4DS & Rht-D1-rPt4471 & 1.0 & 1.3 & $2.0($ VASN2008) \\
\hline & Qfhs.vt-6BL & wPt5176-wPt8268 & 5.1 & ns & $2.5($ VASN2008) \\
\hline FDK (3) & $Q f d k . v t-4 B S$ & wPt6149-tPt0602 & 19.2 & -2.7 & ns \\
\hline DON (3) & Qdon.vt-4DL & wPt3743-wPt6059 & 34.5 & 0.4 & $\begin{array}{l}-0.5 \text { (VASN 2009), } 0.8 \\
\quad \text { (VASN 2008) }\end{array}$ \\
\hline FT (2) & $Q f t . v t-4 D L$ & wPt3743-wPt6059 & 33.5 & 1.1 & ns \\
\hline \multirow[t]{2}{*}{ HT (3) } & Qht.vt-7A & wPt5479-rPt6430 & 18.9 & 1.8 & ns \\
\hline & Qht.vt-2DS & Xwmc112-Xwmc503 & 8.9 & -1.9 & ns \\
\hline \multicolumn{6}{|l|}{ E/MO } \\
\hline \multirow[t]{3}{*}{ INC (4) } & Qfhs.umc-4BS & Rht-B1-Xgwm513 & 2.0 & 3.0 & $\begin{array}{l}4.2 \text { (VASN2008), }-2.8 \\
\text { (VAFLD2009), }\end{array}$ \\
\hline & Qfhs.umc-4DS & Rht-D1 & 0.0 & -4.1 & $\begin{array}{l}-4.1 \text { (VASN2008), } 2.2 \\
\text { (MOSN2008), } 3.0 \\
\text { (VAFLD2009) }\end{array}$ \\
\hline & Qfhs.umc-5AL & Xgwm291-B1 & 20.7 & -1.9 & $\begin{array}{l}-2.0(\text { VASN2008), } \\
-1.7(\text { VASN2009), } 2.6 \\
\text { (VAFLD2009) }\end{array}$ \\
\hline \multirow[t]{4}{*}{ SEV (4) } & Qfhs.umc-2DS & Ppd-D1 & 53.4 & -2.7 & -3.3 (VASN2008) \\
\hline & Qfhs.umc-4BS & Rht-B1-Xgwm513 & 6.0 & 2.2 & $\begin{array}{l}2.7 \text { (VASN2008), }-3.6 \\
\quad \text { (VAFLD2009) }\end{array}$ \\
\hline & Qfhs.umc-4DS & $R h t-D 1-\mathrm{Xbarc} 334 \mathrm{~b}$ & 5.0 & -4.2 & -1.7 (VASN2008) \\
\hline & Qfhs.umc-5AL & Xgwm291-B1 & 20.7 & -1.2 & $\begin{array}{l}-2.4 \text { (VASN2008), } 2.6 \\
\text { (VAFLD2009) }\end{array}$ \\
\hline \multirow[t]{2}{*}{ GH SEV (2) ${ }^{\mathrm{g}}$} & Qfhs.umc-3BL & Xwmc307-Xwmc1 & 17.2 & -6.6 & ns \\
\hline & Qfhs.umc-4BS & Rht-B1-Xgwm513 & 9.0 & -8.3 & ns \\
\hline \multirow[t]{4}{*}{ IND (4) } & Qfhs.umc-2DS & Ppd1-D1 & 53.4 & -1.8 & -2.1 (VASN2008) \\
\hline & Qfhs.umc-4BS & Rht-B1-Xgwm513 & 4.0 & 3.1 & $\begin{array}{l}3.6(\text { VASN2008), }-2.5 \\
\quad(\text { VAFLD2009) }\end{array}$ \\
\hline & Qfhs.umc-4DS & $R h t-D 1-\mathrm{Xbarc} 334 \mathrm{~b}$ & 3.0 & -4.2 & $\begin{array}{l}-3.7 \text { (VASN2008), } 3.2 \\
\quad(\text { VAFLD2009) }\end{array}$ \\
\hline & Qfhs.umc-5AL & Xgwm291-B1 & 20.7 & -1.7 & $\begin{array}{l}-2.2 \text { (VASN2008), } 1.9 \\
\text { (VAFLD2009) }\end{array}$ \\
\hline \multirow[t]{2}{*}{ FDK (3) } & $Q f d k . u m c-4 B S$ & Rht-B1-Xgwm513 & 3.0 & 7.8 & ns \\
\hline & $Q f d k . u m c-4 D S$ & $R h t-D 1$ & 0.0 & -7.5 & $2.0($ VASN2008) \\
\hline \multirow[t]{2}{*}{ GH FDK (2) } & $Q f d k . u m c-3 B L$ & Xwmc653-Xwmc307 & 13.6 & -6.4 & ns \\
\hline & $Q f d k \cdot u m c-4 B S$ & Rht-B1-Xgwm513 & 6.0 & -7.9 & ns \\
\hline
\end{tabular}


Table 1 continued

\begin{tabular}{|c|c|c|c|c|c|}
\hline $\begin{array}{l}\text { FHB variables } \\
\text { and traits }{ }^{\mathrm{a}}\end{array}$ & $\mathrm{QTL}^{\mathrm{b}}$ & Marker interval & $\begin{array}{l}\text { Peak position } \\
(\mathrm{cM})\end{array}$ & Additive $^{c}$ & $\begin{array}{l}\text { Additive } \times \\
\text { environment }^{d}\end{array}$ \\
\hline \multirow[t]{2}{*}{ DON (3) } & Qdon.umc-4DS & $R h t-D 1$ & 0.0 & -0.4 & $\begin{array}{l}0.4 \text { (VASN2008), }-0.6 \\
\quad(\text { VASN2009) }\end{array}$ \\
\hline & Qdon.umc-6AL & XE37M59_4-Xbarc171 & 11.0 & -0.3 & -0.4 (VASN2009) \\
\hline \multirow[t]{2}{*}{ GH DON (2) } & Qfhs.don-3BL & Xwmc307-Xwmc1 & 16.2 & -8.0 & ns \\
\hline & Qfhs.don- $4 B S$ & $R h t-B 1-X g w m 513$ & 5.0 & -7.4 & ns \\
\hline \multirow[t]{2}{*}{ FT (2) } & Qft.umc-2AL & Xgwm122-Xwmc261c & 31.2 & -0.5 & ns \\
\hline & Qft.umc-2DS & Ppd-D1 & 53.4 & 1.2 & $\begin{array}{l}0.6(\text { VASN2008), }-0.7 \\
\quad \text { (VAFLD2009) }\end{array}$ \\
\hline \multirow[t]{4}{*}{ HT (3) } & Qht.umc-2BL & Xgwm630a-Xgwm319 & 12.6 & -3.3 & ns \\
\hline & Qht.umc-2DS & Ppd1-D1 & 53.4 & 2.7 & ns \\
\hline & Qht.umc-4BS & Rht-B1-Xgwm513 & 4.0 & -10.0 & $\mathrm{~ns}$ \\
\hline & Qht.umc-4DS & $R h t-D 1-X b a r c 334$ & 4.0 & 10.8 & ns \\
\hline
\end{tabular}

a Abbreviations for FHB variables, traits, and environments: INC incidence (\%), SEV severity (\%), IND index (0-100), FDK Fusarium damaged kernels (\%), DON deoxynivalenol ( $\mathrm{mg} \mathrm{kg}^{-1}$ ), FT flowering time (d from Jan 1), $H T$ height (cm), B/M Becker/Massey RILs, E/MO Ernie/MO 94-317 RILs, GH Greenhouse, number in the parenthesis after trait is the number of unique environments used to identify significant additive and $\mathrm{A} \times \mathrm{E}$ effects

${ }^{b}$ In the QTL name, vt-B/M RIL population was developed at Virginia Tech, umc-E/MO RIL population was developed at University of Missouri-Columbia

c,d Significant additive effects and interaction effects between main additive effects and environments estimated using QTLNetwork 2.0 (Yang et al. 2008), negative sign of effects means that the QTL allele from the female parents (Becker or Ernie) decreasing FHB or other traits while the positive sign of effects means that the favorable QTL alleles from male parents (Massey or MO 94-317) to decrease FHB or other traits

e The physical bin location of Diversity Array Technology (DArT) markers based on deletion analyses (http://www.cerealsdb.uk.net, accessed on April 15, 2013)

${ }^{\mathrm{f}}$ ns not significant at $P<0.05$

g GH SEV, FDK and DON were re-analyzed using QTLNetwork 2.0 based on data collected from point inoculation tests in Columbia, MO, USA (Liu et al. 2007; Abate et al. 2008)

4BS where the favorable allele $($ Rht-Dla) was from MO 94-317. The three genes, Ppd-Dl, Rht-B1, and Rht-Dl, have pleiotropic effects, with the alleles for photoperiod insensitivity or semi-dwarf stature increasing FHB susceptibility. The allele conferring awnless spikes in Ernie for gene $B 1$ decreased FHB. Independent of these four genes, QTL Qdon.umc-6AL with favorable allele from Ernie, was associated with lower DON. Two other QTL, Qft.umc-2AL and Qht.umc-2BL, decreased FT and HT with alleles from Ernie. Allele Ppd-Dla from MO 94-317 decreased both FT and $\mathrm{HT}$ and $R h t-B l b$ and $R h t-D l b$ reduced height.

$\mathrm{A} \times \mathrm{E}$ interactions in $\mathrm{E} / \mathrm{MO}$ were significant for all four genes (Ppd-Dl, Rht-B1, Rht-Dl, and Bl) associated with FHB variables except for $R h t-B l b$ on FDK and GH SEV, GH FDK, and GH DON. Only Ppd-Dl with FT had a significant A $\times$ E interaction among the five QTL for FT and HT.

Epistasis and interaction effects between epistasis and environments based on two-locus analyses

In $\mathrm{B} / \mathrm{M}$, four pairs of QTL have significant $\mathrm{A} \times \mathrm{A}$ epistases for INC, GH SEV, FDK, and HT but only the pair between Qfhs.vt-4DS and Qfhs.vt-6AS had significant $\mathrm{A} \times \mathrm{A} \times \mathrm{E}$ interactions (Table 2). Two other pairs of QTL only had significant $\mathrm{A} \times \mathrm{A} \times \mathrm{E}$ interactions for INC or IND. Only the pair of QTL for IND, Qfhs.vt-1AS and Qfhs.vt-6BL, were from two QTL with significant additive effects or $\mathrm{A} \times \mathrm{E}$ interactions (Table 1).

In E/MO, Qfhs.umc-4DS (close to Rht-Dl) was involved in seven of the ten $\mathrm{A} \times \mathrm{A}$ epistatic interactions. It had significant effects with $P p d-D 1$ for SEV and IND, with Qdon.umc-6AL for DON, and with the $4 B S$ QTL for SEV, IND, FDK, and HT. In addition, there were significant $\mathrm{A} \times \mathrm{A}$ interactions between the 5AS and 3BL QTL for GH SEV and GH DON with favorable alleles from Ernie. The A $\times$ A interactions between Ppd-Dl and Qft.umc$2 A L$ shortened FT with alleles from Ernie. Significant $\mathrm{A} \times \mathrm{A} \times \mathrm{E}$ interactions only existed between the two QTL on chromosomes 4BS (Rht-Blb) and 4DS (Rht-Dlb) in E/ MO for SEV, IND and FDK. The QTL on chromosome 4DS was involved in most of the epistatic interactions and in all of the $\mathrm{A} \times \mathrm{A} \times \mathrm{E}$ interactions.

Comparisons of FHB resistance among RIL groups with different allelic combinations of genes

A set of $115 \mathrm{~B} / \mathrm{M}$ RILs with different allelic combinations of Rht-Blb, Rht-Dlb, Rht $8 c$, and Ppd-Dla was analyzed 


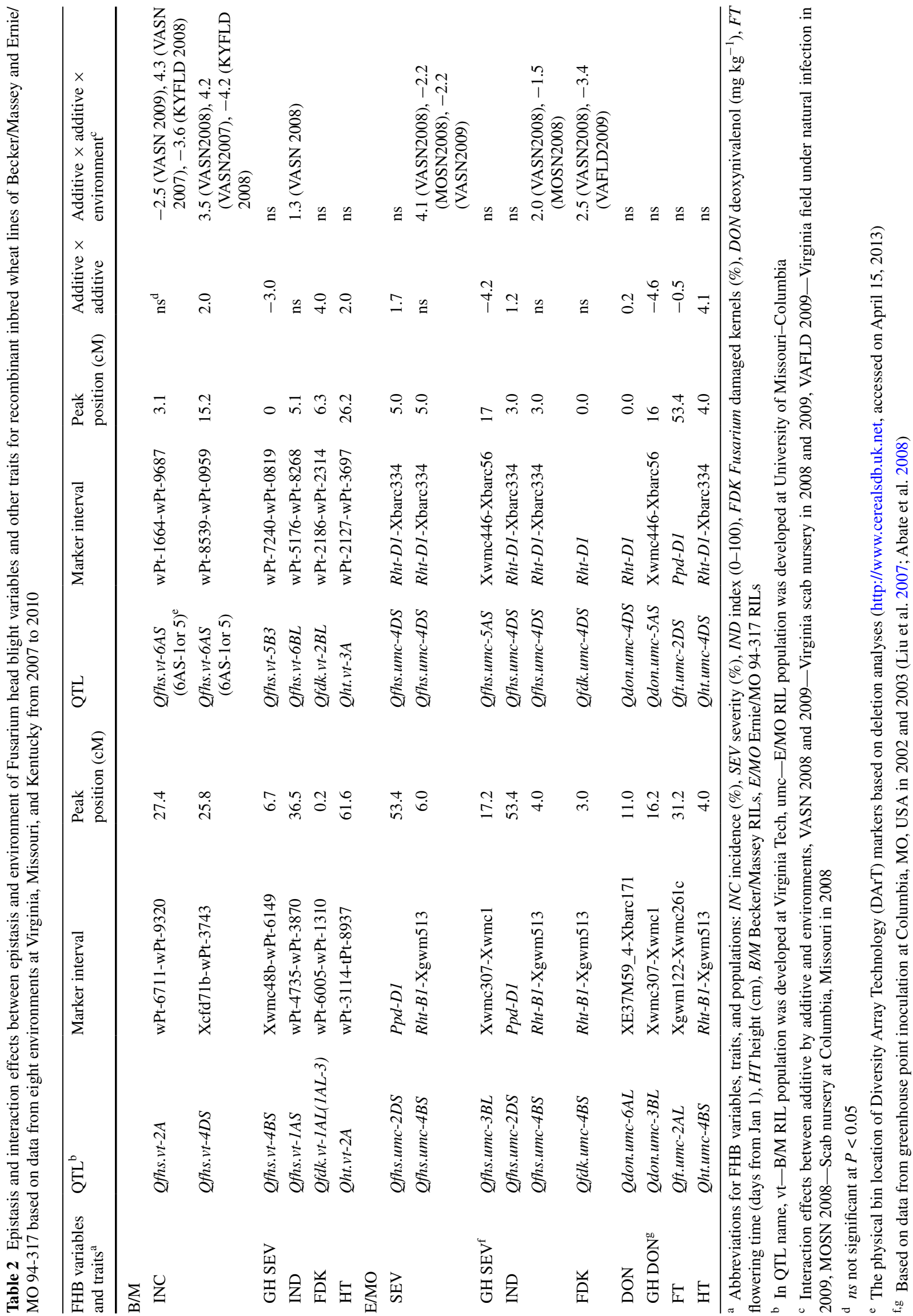


Table 3 Means of Fusarium head blight variables and traits of recombinant inbred line (RIL) groups having different allelic combinations of gene alleles Rht-B1b, Rht-D1b, Rht8c and Ppd-Dla in
Becker/Massey wheat population from 2008 to 2009 Virginia scab nursery and greenhouse severity in 2008

\begin{tabular}{|c|c|c|c|c|c|c|c|c|c|c|}
\hline RIL groups & Allelic combinations & $\begin{array}{l}\text { No. of } \\
\text { RILs }\end{array}$ & $\mathrm{INC}^{\mathrm{a}}$ & SEV & IND & FDK & DON & FT & $\mathrm{HT}^{\mathrm{b}}$ & GHSEV $^{\mathrm{c}}$ \\
\hline 1 & Rht-B1b, Rht8c, Ppd-D1a & 16 & $47.9 \mathrm{ab}$ & $25.8 \mathrm{a}$ & $15.2 \mathrm{ac}$ & $42.6 \mathrm{ac}$ & $4.7 \mathrm{a}$ & $134.1 \mathrm{a}$ & $101.8 \mathrm{a}$ & $56.2 \mathrm{a}$ \\
\hline 2 & Rht-B1b, Rht8c, Ppd-D1b & 4 & $44.4 \mathrm{ab}$ & $19.5 \mathrm{a}$ & $10.8 \mathrm{ab}$ & $39.2 \mathrm{ab}$ & $5.9 \mathrm{a}$ & 137.6a & $111.9 \mathrm{a}$ & $41.9 \mathrm{a}$ \\
\hline 3 & $R h t-D 1 b, R h t 8 c, P p d-D 1 a$ & 15 & $50.9 \mathrm{a}$ & $23.3 \mathrm{a}$ & $14.7 \mathrm{ab}$ & $40.3 \mathrm{ab}$ & $4.6 \mathrm{a}$ & $135.6 \mathrm{a}$ & $104.4 \mathrm{a}$ & $66.1 \mathrm{a}$ \\
\hline 4 & $R h t-D 1 b, R h t 8 c, P p d-D 1 b$ & 3 & $44.6 \mathrm{ab}$ & $23.3 \mathrm{a}$ & $13.9 \mathrm{ab}$ & $41.3 \mathrm{ab}$ & $5.8 \mathrm{a}$ & $136.9 \mathrm{a}$ & $110.0 \mathrm{a}$ & $74.2 \mathrm{a}$ \\
\hline 5 & Rht-B1b, Ppd-Dla & 5 & $43.0 \mathrm{ab}$ & $25.8 \mathrm{a}$ & $13.2 \mathrm{ab}$ & $43.9 \mathrm{ab}$ & $3.2 \mathrm{a}$ & $134.3 \mathrm{a}$ & $109.3 \mathrm{a}$ & $62.0 \mathrm{a}$ \\
\hline 6 & $R h t-B 1 b, P p d-D 1 b$ & 15 & $47.0 \mathrm{ab}$ & $22.4 \mathrm{a}$ & $12.4 \mathrm{ab}$ & $45.2 \mathrm{a}$ & $4.9 \mathrm{a}$ & $137.5 \mathrm{a}$ & $113.7 \mathrm{a}$ & $56.2 \mathrm{a}$ \\
\hline 7 & Rht-D1b, Ppd-Dla & 8 & $54.4 \mathrm{a}$ & $25.1 \mathrm{a}$ & $17.0 \mathrm{a}$ & $43.2 \mathrm{ab}$ & $4.0 \mathrm{a}$ & $135.7 \mathrm{a}$ & $103.5 \mathrm{a}$ & $62.9 \mathrm{a}$ \\
\hline 8 & Rht-D1b, Ppd-D1b & 5 & $42.3 \mathrm{ab}$ & $18.5 \mathrm{a}$ & $9.7 \mathrm{ab}$ & $41.9 \mathrm{ab}$ & $5.9 \mathrm{a}$ & $138.9 \mathrm{a}$ & $116.8 \mathrm{a}$ & $60.9 a$ \\
\hline 9 & Rht $8 c$, Ppd-Dla & 18 & $37.1 \mathrm{~b}$ & $20.2 \mathrm{a}$ & $8.5 b$ & $28.9 b$ & $3.5 \mathrm{a}$ & $134.7 \mathrm{a}$ & $108.7 \mathrm{a}$ & $70.5 \mathrm{a}$ \\
\hline 10 & $R h t 8 c, P p d-D 1 b$ & 11 & $39.0 \mathrm{ab}$ & $20.7 \mathrm{a}$ & $9.6 \mathrm{ab}$ & $28.4 \mathrm{bc}$ & $4.5 \mathrm{a}$ & $135.8 \mathrm{a}$ & $107.1 \mathrm{a}$ & $59.1 \mathrm{a}$ \\
\hline 11 & Ppd-Dla & 3 & $33.0 \mathrm{ab}$ & $17.8 \mathrm{a}$ & $6.3 \mathrm{abc}$ & $29.3 \mathrm{ab}$ & $3.9 \mathrm{a}$ & $136.3 \mathrm{a}$ & $103.0 \mathrm{a}$ & $55.6 \mathrm{a}$ \\
\hline \multirow[t]{3}{*}{12} & Ppd-D1b & 12 & $39.2 \mathrm{ab}$ & 19.1a & $8.4 \mathrm{bc}$ & $34.6 a b$ & $4.2 \mathrm{a}$ & $137.4 \mathrm{a}$ & $113.9 \mathrm{a}$ & $70.1 \mathrm{a}$ \\
\hline & $\mathrm{HSD}^{\mathrm{e}}$ & & 21.5 & 9.9 & 10.1 & 21.2 & 4.2 & 7.7 & 24.3 & 41.7 \\
\hline & Minimum HSD & & 13.2 & 6.1 & 6.2 & 13.0 & 2.6 & 4.7 & 15.0 & 25.7 \\
\hline
\end{tabular}

${ }^{a}$ Abbreviations of FHB variables and traits: INC incidence (\%), SEV severity (\%), IND index (0-100), FDK Fusarium damaged kernels (\%), $D O N$ deoxynivalenol $\left(\mathrm{mg} \mathrm{kg}^{-1}\right), F T$ flowering time (days from Jan 1), $H T$ height (cm), $G H$ greenhouse

${ }^{\mathrm{b}}$ HT (height) was only measured from VASN in 2009

${ }^{c}$ Severity from greenhouse based on point inoculation. B/M RILs were screened in VAGH in 2008

d Means followed by the same letter within a column are not significantly different at $P<0.05$. The significance was set based on the SAS output of pairwise comparisons converted into letters

e Tukey's studentized range (HSD) values were calculated based on Harmonic means of number of lines in all 12 groups; minimum HSD values were calculated by using the harmonic means of two groups with the largest number of lines

using the group means of all traits including FT, HT and FHB variables from VASN in 2008 and 2009 (Table 3). The few double dwarf (Rht-Blb and Rht-DIb) RILs were excluded in the mean comparisons as their growth was abnormal in general. RILs in group 7 (Rht-Dlb, Ppd-Dla) had higher INC and IND, and those in group 6 (Rht-Blb, $P p d-D l b)$ had higher FDK than those in group 9 (Rhtsc, Ppd-Dla). There were no significant differences among RIL groups for SEV, DON, FT, HT, or GHSEV, which may have been the result of the relatively small sample size within some groups. When alleles of other genes are same, the Ppd-Dla group was 1.1-3.5 days earlier in FT and 4.4$13.3 \mathrm{~cm}$ shorter than those of the Ppd-DIb groups except for HT in groups 9 and 10 (Table 3).

In the E/MO population, 12 groups of RILs composed of various allelic combinations of four genes including $B 1$, $R h t-B 1 b, R h t-D 1 b$, and Ppd-Dla were analyzed for differences among FHB variable and trait means (Table 4). Among 191 RILs, group 7 (Rht-D1b, Ppd-Dla) had the earliest FT and highest INC, SEV, and IND. The RILs in groups 1-8 were shorter in HT and had high values for INC, SEV, IND, FDK, and DON. As in the B/M population, comparisons among E/MO RIL groups differing only for $P p d-D 1$ alleles indicate that groups having the Ppd-Dla allele tended to flower earlier (1.6-6.1 days) and were shorter in height $(2.2-6.9 \mathrm{~cm})$ than those with $P p d-D 1 b$. Groups of RILs with one dwarfing gene had intermediate HT ranging from 90.7 to $100.3 \mathrm{~cm}$ while those without dwarf genes ranged from 105.3 to $112.1 \mathrm{~cm}$. In both populations, RILs with semi-dwarfing genes Rht-Blb or Rht$D 1 b$ tended to have higher values for FHB variables than RILs lacking dwarfing genes.

Parental alleles of linked markers for common QTL

Tightly linked markers and base pair sizes of parental alleles for genes and QTL associated with FHB resistance are presented for the B/M and E/MO populations (Supplementary Table S3). These markers have been used to screen elite breeding lines from $>10$ SRW wheat breeding programs by the USDA-ARS Genotyping Center at Raleigh, NC, USA (http://www.ars.usda.gov/Main/docs.ht m?docid=19523\&page $=4)$. The two regional experiments are Northern Uniform Winter Wheat Scab Nursery (NUWWSN, 60 entries) and Uniform Southern Fusarium Head Blight Nursery (USFHBN, 51 entries). A set of 43 (72\%) and $22(43 \%)$ lines had Ppd-Dlb while only a few had $R h t 8 c$. About 5-30 \% may have the 3BL QTL conditioning 
Table 4 Means of Fusarium head blight variables and traits of recombinant inbred line (RIL) groups having different allelic combinations of gene alleles $B 1$, Rht-B1b, Rht-D1b, and Ppd-D1a in Ernie/
MO 94-317 wheat population from 2008 to 2009 scab nursery and greenhouse severity in 2002 and 2003

\begin{tabular}{|c|c|c|c|c|c|c|c|c|c|c|}
\hline RIL groups & $\begin{array}{l}\text { Allelic } \\
\text { combinations }\end{array}$ & No. of RILs & $\mathrm{INC}^{\mathrm{a}}$ & SEV & IND & FDK & DON & FT & $\mathrm{HT}^{\mathrm{b}}$ & GHSEV $^{\mathrm{c}}$ \\
\hline 1 & B1, Rht-B1b, Ppd-D1a & 15 & $45.9 \mathrm{abc}$ & 31.5bde & $18.3 \mathrm{bd}$ & $42.6 \mathrm{ac}$ & $2.3 \mathrm{a}$ & $134.8 \mathrm{~cd}$ & $96.9 \mathrm{de}$ & $63.9 \mathrm{ab}$ \\
\hline 2 & $B 1$, Rht-B1b, Ppd-D1b & 13 & 40.0bde & $23.3 \mathrm{cde}$ & $12.1 \mathrm{cde}$ & $49.1 \mathrm{a}$ & $3.0 \mathrm{a}$ & $138.9 \mathrm{ab}$ & $99.2 \mathrm{~b}-\mathrm{e}$ & $56.1 \mathrm{ab}$ \\
\hline 3 & B1, Rht-D1b, Ppd-D1a & 12 & 46.0a-d & 32.7abd & $18.7 \mathrm{bd}$ & $48.0 \mathrm{ac}$ & $3.1 \mathrm{a}$ & $134.4 \mathrm{~cd}$ & $90.7 \mathrm{e}$ & $75.4 \mathrm{a}$ \\
\hline 4 & B1, Rht-D1b, Ppd-D1b & 6 & 44.4a-e & 21.4bce & 15.1bde & $51.1 \mathrm{ac}$ & $3.4 \mathrm{a}$ & $140.6 \mathrm{a}$ & $93.8 \mathrm{de}$ & $57.6 a b$ \\
\hline 5 & Rht-B1b, Ppd-D1a & 9 & 49.9abc & $36.9 \mathrm{ab}$ & $23.8 \mathrm{ab}$ & $36.6 a b c$ & $2.3 \mathrm{a}$ & $134.8 \mathrm{bcd}$ & $93.7 \mathrm{de}$ & $43.6 b$ \\
\hline 6 & Rht-B1b, Ppd-D1b & 16 & $48.8 \mathrm{abc}$ & 30.7bde & $19.2 \mathrm{bc}$ & $40.1 \mathrm{ac}$ & $3.1 \mathrm{a}$ & $137.8 \mathrm{abc}$ & 100.3a-e & $55.8 \mathrm{ab}$ \\
\hline 7 & $R h t-D 1 b$, Ppd-D1a & 12 & $56.5 \mathrm{a}$ & $43.6 \mathrm{a}$ & $28.9 \mathrm{a}$ & $32.9 \mathrm{bcd}$ & $3.3 \mathrm{a}$ & $133.6 \mathrm{~d}$ & $96.3 \mathrm{de}$ & $69.2 \mathrm{ab}$ \\
\hline 8 & $R h t-D 1 b, P p d-D 1 b$ & 18 & $51.5 \mathrm{ab}$ & $27.0 \mathrm{~b}-\mathrm{e}$ & $17.0 \mathrm{bd}$ & $39.4 \mathrm{ac}$ & $3.6 \mathrm{a}$ & $139.1 \mathrm{a}$ & $100.0 \mathrm{~b}-\mathrm{e}$ & $59.3 \mathrm{ab}$ \\
\hline 9 & B1, Ppd-D1a & 22 & 33.0de & $21.9 \mathrm{ce}$ & $9.3 \mathrm{e}$ & $22.9 \mathrm{bd}$ & $1.8 \mathrm{a}$ & $134.3 \mathrm{~d}$ & $107.7 \mathrm{a}-\mathrm{d}$ & $69.5 \mathrm{a}$ \\
\hline 10 & B1, Ppd-D1b & 32 & $32.0 \mathrm{e}$ & $20.2 \mathrm{ce}$ & $7.7 \mathrm{e}$ & $25.3 \mathrm{bd}$ & $2.4 \mathrm{a}$ & $137.1 \mathrm{abc}$ & 109.9ab & $64.4 \mathrm{ab}$ \\
\hline 11 & Ppd-Dla & 18 & 38.5 cde & $26.4 \mathrm{ce}$ & 13.1cde & $22.5 \mathrm{bd}$ & $2.6 \mathrm{a}$ & $134.8 \mathrm{~cd}$ & 105.3a-d & $65.3 \mathrm{ab}$ \\
\hline \multirow[t]{3}{*}{12} & $P p d-D 1 b$ & 18 & $36.6 \mathrm{cde}$ & $19.8 \mathrm{ce}$ & $9.7 \mathrm{de}$ & $20.3 d$ & $2.3 \mathrm{a}$ & $136.6 a-d$ & $112.1 \mathrm{a}$ & $62.9 \mathrm{ab}$ \\
\hline & $\mathrm{HSD}^{\mathrm{e}}$ & & 14.8 & 11.3 & 9.6 & 14.7 & 2.3 & 3.8 & 13.7 & 24.5 \\
\hline & Minimum HSD & & 10.6 & 8.1 & 6.9 & 10.6 & 1.7 & 2.7 & 9.8 & 17.6 \\
\hline
\end{tabular}

${ }^{a}$ Abbreviations of traits: INC incidence (\%), SEV severity (\%), IND index (0-100), FDK Fusarium damaged kernels (\%), DON deoxynivalenol $\left(\mathrm{mg} \mathrm{kg}^{-1}\right), F T$ flowering time (days from Jan 1), HT height (cm), GH greenhouse

${ }^{\mathrm{b}}$ HT (height) was only measured from VASN in 2009

${ }^{c}$ Severity from greenhouse based on point inoculation. E/MO RILs were screened at Columbia, MO in 2002 and 2003 (Liu et al. 2007 ; Abate et al. 2008)

${ }^{\mathrm{d}}$ Means followed by the same letter within a column are not significantly different at $P<0.05$. The significance was set based on the SAS output of pairwise comparisons converted into letters. "-"between letters represents those letters omitted between these two border letters

e Tukey's studentized range (HSD) values were calculated based on Harmonic means of number of lines in all 12 groups; Minimum HSD values were calculated by using the harmonic means of two groups with the largest number of lines

GH SEV resistance. About 45-70 \% of the tested lines have alternative wild alleles of $R h t-B 1$ or $R h t-D 1$ to reduce the values of FHB variables.

\section{Discussion}

Correlation among FHB variables and other morphological traits

The FHB variables INC, SEV, IND, and FDK were highly and significantly correlated with each other in both populations in diverse environments (Supplementary Table S2). Correlations of DON concentration with INC and FDK also were significant in most environments, while DON was not significantly associated with SEV in most of the tests. This suggests that DON concentration in most environments is determined to a larger extent by FHB incidence (percentage of infected spikes) than severity (percentage of diseased spikelets per spike). The concentration of DON in grain also is affected by the type and prevalence of F. graminearum isolates ( $3 \mathrm{ADON}, 15 \mathrm{ADON})$ and by the prevailing environmental conditions from spike emergence to grain harvest (Cowger et al. 2009). FT and HD were positively related with DON at VAFLD in 2009, which might indicate that genotypes having early heading and flowering times escaped the optimal infection conditions, thus resulting in lower DON.

\section{Comparison of mapped QTL to previously known QTL}

The chromosome locations of QTL mapped in this study were compared with previously mapped QTL based on two wheat consensus maps, one meta-analysis QTL map, and two DArT marker maps. The two wheat consensus maps are integrated maps (Somers et al. 2004) and the International Triticeae Mapping Initiative maps (ITMI) (Song et al. 2005) containing GWM, WMC, and BARC SSR markers with bin maps confirmed are from Sourdille et al. (2004). The meta-analysis map of QTL for FHB resistance includes most mapped QTL from sources worldwide reported from 2001 to 2009 (Liu et al. 2009). The two DArT marker maps integrated DArT and SSR markers using double haploid populations derived from Cranbrook to Halberd (Kammholz et al. 2001) and from Arina to NK93604 (Semagn et al. 2006, 2007). If the DArT markers 


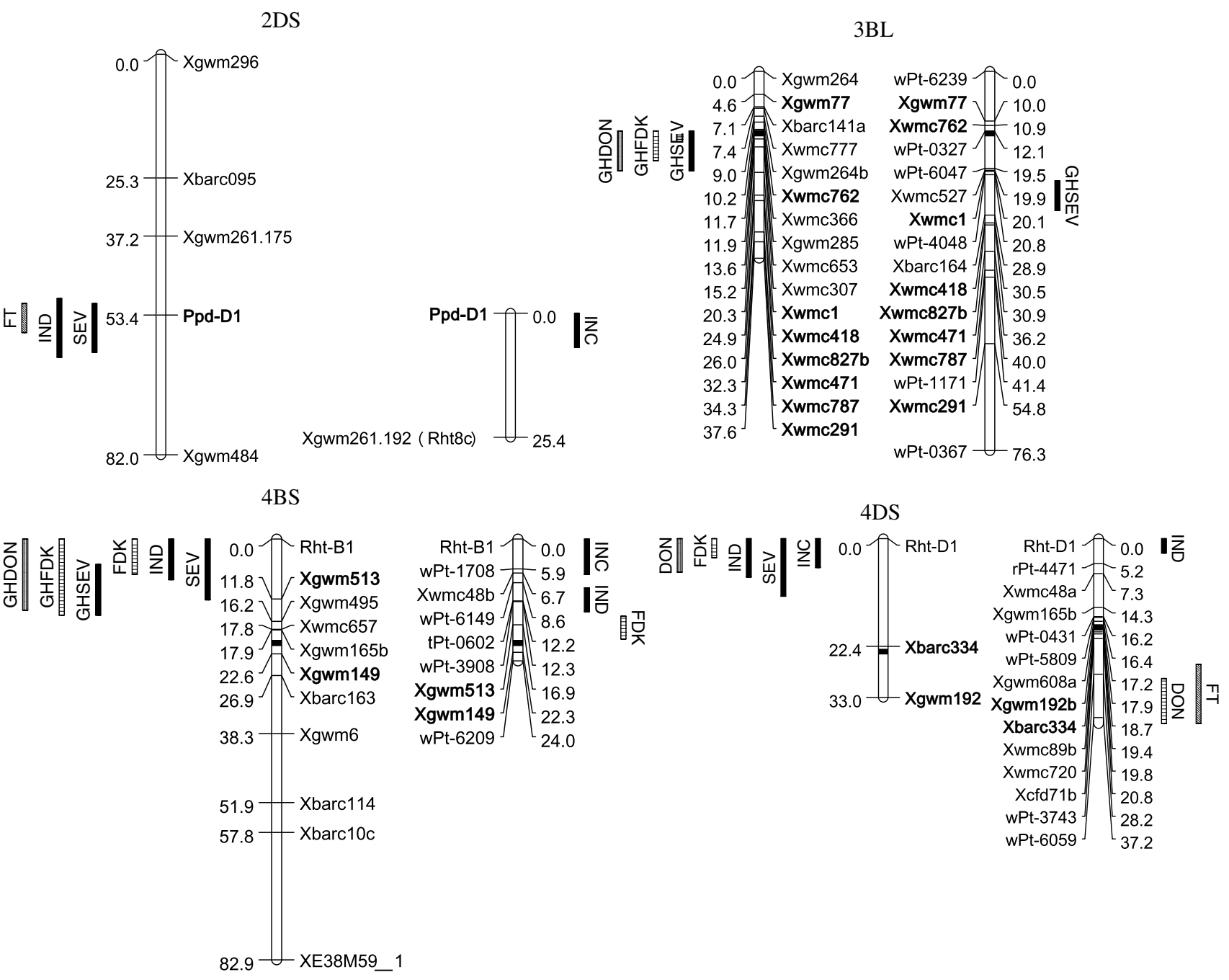

Fig. 1 Four common quantitative trait loci (QTL) associated with Fusarium head blight (FHB) variables and other traits in Ernie/MO 94-317 (E/MO, left) and Becker/Massey (B/M, right) populations. For each pair of chromosomes and QTL bars, the one on the left is for $\mathrm{E} / \mathrm{MO}$ and the one on the right is for $\mathrm{B} / \mathrm{M}$. Markers in common on chromosomes in both populations are in bold font. The bar length is the range of the QTL significant regions $(P<0.05)$ from the output of QTLNetwork 2.0 (Yang et al. 2008). The label for each QTL of FHB variables besides the bar is: INC incidence (\%), SEV

are absent on these two maps, DArT markers and their genetic and physical chromosome locations were referenced from the Triticarte (http://www.triticarte.com.au/content/further_development.html, accessed on April 1, 2013) and cereals DB (Wilkinson et al. 2012, www.cerealsdb. uk.net, accessed on April 15, 2013) websites.

All four significant QTL common in B/M and E/MO populations on chromosomes 2DS, 3BL, 4BS, and 4DS can be aligned based on linked SSR markers on consensus maps and the meta-analysis QTL map (Fig. 1). In addition, Qfhs.umc-5AL overlapped the $B 1$ gene in E/MO and awnless plants had lower FHB, which is consistent with what severity (\%), IND index (0-100), FDK Fusarium damaged kernels (\%), DON deoxynivalenol $\left(\mathrm{mg} \mathrm{kg}^{-1}\right), F T$ flowering time (days from Jan 1), HT height (cm), 'GH' in front of FHB variables means the data from point inoculation in the greenhouse, $\mathrm{B} / \mathrm{M}$ data were from the greenhouse at Blacksburg, Virginia, in 2007 and 2008 while E/MO data were from the greenhouse at Columbia, Missouri, in 2002 and 2003 (Liu et al. 2007; Abate et al. 2008). The genetic maps and graphs were drawn using MapChart 2.0 (Voorrips 2002)

Gervais et al. (2003) found in the European cultivar Renan. Other QTL, Qfhs.vt-1AS, Qfhs.vt-1DS, Qfhs.vt-2BL, Qdon. $v t-4 D L$ in $\mathrm{B} / \mathrm{M}$ and $Q d o n . u m c-6 A L$ in $\mathrm{E} / \mathrm{MO}$, are independent of the morphological genes evaluated in the current study.

In B/M, DArT marker wPt-3870 linked to Qfhs.vt-1AS was located at bin 1AS-3 where Xgwm33 and Xwmc818 are located. Marker Xwmc818 was reported to be linked to QTL for SEV in Pirat (Rht-Dlb) (Holzapfel et al. 2008). A QTL for DON accumulation was located in the same region of Wheaton (Yu et al. 2008; Liu et al. 2009). The marker wPt-7946 linked to Qfhs.vt-lDS is very close to 
wPt-3738 which is in bin 1DS-5. Marker Xbarc149 in this region was reported to be linked to a QTL from Pirat (Holzapfel et al. 2008). The DArT marker wPt-0628 linked to Qfhs.vt-2BL was located in bin 2BL-6 where Xgwm501 and Xgwm47 are located. These two markers were associated with lower SEV in Ning 7840, SD97060, and G1692 (Zhou et al. 2002; Malla et al. 2010; Schmolke et al. 2008). The DArT marker wPt-3132 linked to the $2 \mathrm{BL}$ QTL in the current study also was linked to the QTL in SD97060. Markers wPt-5809 and wPt-0431 are $20 \mathrm{cM}$ away from wPt-3743 to wPt-6509, which places the latter on chromosome 4DL region close to markers Xwmc331 and Xwmc457 where a meta-QTL from DH181 for INC and FDK, and from Arina for FDK was present (Yang et al. 2005; Draeger et al. 2007; Liu et al. 2009).

The QTL Qdon.umc-6AL from E/MO, linked to marker Xbarc171, was close to Xbarc107 that was associated with type II resistance in Apache, Dream, and Spark (Holzapfel et al. 2008; Schmolke et al. 2005; Srinivasachary et al. 2008).

Qfhs.vt-3BL and $Q f h s . u m c-3 B L$ are in the same region as the QTL identified in the Swiss winter wheat cultivar Arina (Paillard et al. 2004), French cultivar Apache (Holzapfel et al. 2008) and Chinese landrace Wangshuibai (Zhou et al. 2004; Yu et al. 2008) which were associated with reduced FHB severity in greenhouse and/or field experiments. This QTL was placed near the centromere of chromosome 3BS based on markers Xgwm77, Xgwm285, and Xgwm376 on the ITMI map (Song et al. 2005). Results from the current study including additional SSR markers, Xwmc1, Xwmc418, and Xwmc827, indicated that this QTL likely is located on $3 \mathrm{BL}$, which is consistent with the integrated map of Somers et al. (2004). This 3BL QTL is the only common QTL associated with greenhouse SEV in both populations with additional effects on reducing FDK and DON by alleles from Ernie (Liu et al. 2007; Abate et al. 2008) (Table 1; Fig. 1).

The QTL on chromosome 2DS is in the same region as QTL associated with FHB INC, SEV, and DON in Sumai 3 (Handa et al. 2008), SEV in cultivars Biscay and Romanus (Holzapfel et al. 2008), and Chinese landrace Wangshuibai (Jia et al. 2005) based on the chromosome locations of markers Xgwm261 and Xgwm484 (Fig. 1). This QTL was located at the Ppd-D1 locus in both populations in this study; however, $P p d-D 1$ was not mapped in those three above-mentioned studies (Table 1; Fig. 1). In most environments, Ppd-Dla is associated with early head emergence and shorter plant height. Since infection of wheat heads occurs near flowering time, differences among genotypes in flowering date and plant height and environmental conditions during this period can potentially influence initial infection and disease development. In the current study, spray inoculations were conducted according to the flowering time to minimize the effects of different flowering time and height on FHB infection. In E/MO, the photoperiod-sensitive allele, $P p d-D 1 b$ from Ernie, was associated with lower SEV and IND, later flowering time, and taller plant height, while the $P p d-D 1 b$ from Massey only decreased INC in B/M among the six environments (Table 1). The Ppd-Dla allele had smaller effects on reducing $\mathrm{HT}$ and increasing $\mathrm{FHB}$ variables when compared with those of $R h t-B 1 b$ and $R h t-D 1 b$ based on the magnitude of additive effects and group means with only alleles of $R h t-B 1 b, R h t-D 1 b$, and Ppd-Dla, especially in E/MO (Tables 1, 3, 4).

The QTL on chromosome 4BS in both populations are in a region overlapping gene $R h t-B 1$ where QTL have been identified for type I resistance (FHB incidence) in Wuhan 1 (Somers et al. 2003) and Wangshuibai (Lin et al. 2006), type II resistance (FHB severity) in greenhouse studies in Ernie (Liu et al. 2007) and Wangshuibai (Jia et al. 2005), and resistance to DON accumulation and kernel damage (FDK) in two SRW wheat genotypes Ernie (Abate et al. 2008) and IL94-1653 (Bonin and Kolb 2009) based on markers Xgwm513, Xgwm495, and Xgwm149 (Somers et al. 2004). However, in the current study, the favorable QTL alleles for all the FHB variables except GHSEV, GH FDK, and GH DON were derived from the susceptible parents, Becker or MO 94-317 that have the wild-type allele Rht-Bla (Table 1). In E/MO, the 4BS QTL decreased INC, SEV, IND, and FDK based on data field spray inoculation.

The QTL on chromosome 4DS are in a region close to gene Rht-Dl where major QTL have been previously identified and associated with FHB incidence and severity in the cultivars Soissons and Spark (Srinivasachary et al. 2009, 2008), Apache, History, Romanus (Holzapfel et al. 2008), and Arina (Draeger et al. 2007) based on the chromosome locations of $R h t-D 1$ and SSR markers Xbarc334 and Xgwm192. Similar to that of Ernie and Massey, these six European wheat cultivars have Rht-Dla which provided the resistance to FHB. The Qdon.vt-4DL from Massey to Qdon.umc-4DS from Ernie co-localized with two metaQTL on chromosome 4DL and 4DS, respectively (Liu et al. 2009). QTL Qdon.vt-4DL on 4DL for DON and Qfdk.umc$4 D S$ on $4 \mathrm{DS}$ for FDK have not been reported previously in other sources.

In E/MO, the semi-dwarfing alleles $R h t-B 1 b$ and $R h t$ $D 1 b$ on chromosomes 4BS and 4DS decreased plant height by $10.0-10.8 \mathrm{~cm}$ (Table 1$)$. The pleiotropic effects of Rht$B 1 b$ and $R h t-D 1 b$ observed in E/MO and B/M are consistent with previous reports of association between these two dwarfing genes with FHB susceptibility in European wheat cultivars (Srinivasachary et al. 2008; Hilton et al. 1999; Draeger et al. 2007). In tests conducted in Germany (Knopf et al. 2008) and the UK (Gosman et al. 2007) that included wheat cultivars with dwarfing gene allele $R h t-B 1 b$ or Rht$D 1 b$, cultivars having $R h t-D l b$ were more susceptible 
to FHB and had higher disease incidence than standard height cultivars $(R h t-D l a)$. Srinivasachary et al. (2009) also reported that both $R h t-B 1 b$ and $R h t-D 1 b$ decrease FHB type I resistance, yet $R h t-B l b$ could significantly increase type II resistance based on point inoculation of near-isogenic lines which were derived from cultivars Mercia and Maris Huntsman. Similar results were observed in the current study for both cultivars, Ernie and Massey, in greenhouse point inoculation studies.

Effects of QTL, dwarfing genes, and Ppd-Dl on FHB resistance and impacts on breeding

The 3BL QTL has been identified in cultivars and diverse germplasm in Europe (Paillard et al. 2004; Holzapfel et al. 2008), China (Zhou et al. 2004; Yu et al. 2008), and the US (Liu et al. 2007; Abate et al. 2008). Therefore, availability of tightly linked markers, such as those identified in the current study (Supplementary Table S3), will facilitate marker-assisted selection of this QTL in existing breeding populations to develop cultivars with Type II resistance, lower in FDK and DON (Abate et al. 2008). Success in combining the 3BL QTL with gene Fhbl, located on 3BS, will depend on the degree of linkage and whether current lines having both of these in coupling exist.

The Ppd-D1, Rht-B1, and Rht-Dl genes have pleiotropic effects on HT and FHB variables. The alleles $P p d-$ $D l b, R h t-B l a$, and Rht-Dla reduce FHB and increase HT (Table 1). The $B 1$ gene from Ernie was associated with lower FHB INC and SEV (Table 1). Lines in both populations lacking either dwarfing gene, Rht-Blb or $R h t-D 1 b$, have lower values for FHB variables, such as group 8 (Rht8c, Ppd-Dla) (Table 3, 4); therefore, use of $R h t 8 c$ and other dwarfing genes with a similar mode of action likely would be beneficial in breeding programs where FHB is a major priority. However, significant variation for FHB resistance exists among wheat genotypes with $R h t-B 1 b$ or $R h t-D 1 b$, thus it should be feasible to select high yielding semi-dwarf lines having moderateto-high levels of FHB resistance (Voss et al. 2008). This is consistent with results from previous studies involving significant epistasis between Rht-Dlb and Ppd-Dla (or Qdon.umc-6AL) with FHB wherein it was postulated that wheat breeders can find germplasm lines containing various combinations of these genes and resistance QTL to minimize pleiotropic effects of these genes on FHB susceptibility. While many US soft red winter cultivars with Rht-DIb are susceptible to FHB, a few cultivars having Rht-Dlb, such as Roane (Griffey et al. 2001), Tribute (Griffey et al. 2005), and Jamestown (Griffey et al. 2010), express moderate levels of FHB resistance similar to that of Ernie with $R h t-B 1 b$ (McKendry et al. 1995; Liu et al. 2005, 2007, 2009).
Among 13 QTL for FHB variables identified in the two populations, only Qfhs.vt-1AS did not have significant $\mathrm{A} \times \mathrm{E}$ interactions; however, it has significant $\mathrm{A} \times \mathrm{A} \times \mathrm{E}$ interactions. In $\mathrm{E} / \mathrm{MO}$, the $\mathrm{A} \times \mathrm{A}$ interactions of $R h t-B 1 b$ and $R h t-D 1 b$ were not significant for SEV, IND, and FDK, while their corresponding $\mathrm{A} \times \mathrm{A} \times \mathrm{E}$ interactions were significant (Table 2). These interactions indicated the complication of FHB resistance. The model used to estimate both main effects and interaction effects of QTL and QTL $\times$ E provides an unbiased estimate of QTL main effects and a better understanding of a complex trait, like FHB resistance (Kumar et al. 2007).

In summary, this study characterized FHB resistance in two US soft red winter wheat cultivars. Four significant common QTL associated with INC, SEV, IND, FDK and DON were identified, and all of them overlapped other meta-QTL from FHB-resistant sources worldwide based on common linked molecular markers. Three of them overlapped genes governing plant height (Rht-BI and $R h t-D 1)$ and photoperiod sensitivity (Ppd-Dl). The pleiotropic effects of $R h t-B 1 b$ and $R h t-D 1 b$ in E/MO and $\mathrm{B} / \mathrm{M}$ are consistent with results from previous studies of European wheat cultivars (Srinivasachary et al. 2008; Hilton et al. 1999; Draeger et al. 2007). The current study evaluated the direct association of these genes with FHB resistance in two US wheat cultivars. Results suggest that incorporating and pyramiding FHB resistance QTL using wheat genotypes having desirable morphological genes, such as Ppd-Dla and Rht-Blb, can be an effective strategy to improve FHB resistance using marker-assisted selection.

Acknowledgments The authors thank P. Gundrum, N. McMaster, B. Will, J. Seago, G. Berger, M. Christopher, P. O'Boyle, M. Vaughn, R. Pitman, T. Lewis, D. Donavan, and D. Reaver from Virginia Tech for their technical support. Additional data were kindly provided by D. Tague from University of Missouri-Columbia, N. Mundell from University of Kentucky, J. Smith and M. Xiong from USDA-ARS genotyping center at Raleigh, NC. Funding for this project was provided by the Virginia Small Grains Board, the Virginia Agricultural Council, and the US Department of Agriculture under Agreement No. 59-0790-4-102. Any opinions, findings, conclusions, or recommendations expressed in this publication are those of the authors and do not necessarily reflect the view of the US Department of Agriculture.

Open Access This article is distributed under the terms of the Creative Commons Attribution License which permits any use, distribution, and reproduction in any medium, provided the original author(s) and the source are credited.

\section{References}

Abate Z, Liu S, McKendry AL (2008) Quantitative trait loci associated with deoxynivalenol content and kernel quality in the soft red winter wheat Ernie. Crop Sci 48:1408-1418 
Akbari M, Wenzl P, Caig V, Carling J, Xia L, Yang S et al (2006) Diversity arrays technology (DArT) for high-throughput profiling of the hexaploid wheat genome. Theor Appl Genet 113:1409-1420

Bai GH, Shaner G (1994) Scab of wheat-prospects for control. Plant Dis 78:760-766

Bonin CM, Kolb FL (2009) Resistance to Fusarium head blight and kernel damage in a winter wheat recombinant inbred line population. Crop Sci 49:1304-1312

Buerstmayr H, Ban T, Anderson JA (2009) QTL mapping and marker-assisted selection for Fusarium head blight resistance in wheat: a review. Plant Breed 128:1-26

Christopher MD, Liu SY, Hall MD, Marshall DS, Fountain MO, Johnson JW, Milus EA, Garland-Campbell KA, Chen X, Griffey CA (2013) Identification and mapping of adult-plant stripe rust resistance in soft red winter wheat cultivar USG 3555. Plant Breed 132:53-60

Cowger C, Patton-Özkurt J, Brown-Guedira G, Perugini L (2009) Post-anthesis moisture increased Fusarium head blight and deoxynivalenol levels in North Carolina winter wheat. Phytopathology 99:320-327

Draeger R, Gosman N, Steed A, Chandler E, Thomsett M, Srinivasachary, Schondelmaier J, Buerstmayr $\mathrm{H}$, Lemmens $\mathrm{M}$, Schmolke M, Mesterhazy A, Nicholson P (2007) Identification of QTLs for resistance to Fusarium head blight, DON accumulation and associated traits in the winter wheat cultivar Arina. Theor Appl Genet 115:617-625

Gervais L, Dedryver F, Morlais JY, Bodusseau V, Negre S, Bilous M, Groos C, Trottet M (2003) Mapping of quantitative trait loci for field resistance to Fusarium head blight in an European winter wheat. Theor Appl Genet 106:961-970

Gilsinger J, Kong L, Shen X, Ohm H (2005) DNA markers associated with low Fusarium head blight incidence and narrow flower opening in wheat. Theor Appl Genet 110:1218-1225

Gooding RW, Lafever HN, Campbell KG, Herald LD (1997) Registration of freedom wheat. Crop Sci 37:1007

Gosman N, Bayles R, Jennings P, Kirby J, Nicholson P (2007) Evaluation and characterization of resistance to Fusarium head blight caused by Fusarium culmorum in UK winter wheat cultivars. Plant Pathol 56:264-276

Griffey CA, Starling TM, Price AM, Sisson WL, Das MK, Pridgen TH, Vaughn ME, Rohrer WL, Brann DE (2001) Registration of 'Roane' wheat. Crop Sci 41:1359-1360

Griffey CA, Rohrer WL, Pridgen TH, Brooks WS, Chen J, Wilson JA, Nabati D, Brann DE, Rucker EG, Behl HD, Vaughn ME, Sisson WL, Randall TR, Corbin RA, Kenner JC, Dunaway DW, Pitman RM, Smid AE, Bockelman HE, Gaines C, Long DL, McVey DV, Cambron SE, Whitcher L (2005) Registration of 'Tribute' wheat. Crop Sci 45:419-420

Griffey CA, Thomason WE, Pitman RM, Beahm BR, Paling JJ, Chen J, Fanelli JK, Kenner JC, Dunaway DW, Brooks WS, Vaughn ME, Hokanson EG, Behl HD, Corbin RA, Hall MD, Liu S, Custis JT, Waldenmaier CM, Starner DE, Gulick SA, Ashburn SR, Whitt DL, Bockelman HE, Souza EJ, Brown-Guedira GL, Kolmer JA, Long DL, Jin Y, Chen X, Cambron SE (2010) Registration of 'Jamestown' wheat. J Plant Reg 4:28-33

Gupta A, Lipps PE, Campbell KG, Sneller CH (2001) Identification of QTL associated with resistance to FHB in Ning7840 and freedom. In: Canty SM, Lewis J, Siler L, Ward RW (eds) Proceedings of the 2001 national Fusarium head blight forum. Michigan State University, East Lansing, p 180

Handa H, Namiki N, Xu D, Ban T (2008) Dissecting of the FHB resistance QTL on the short arm of wheat chromosome 2D using a comparative genomic approach: from QTL to candidate gene. Mol Breed 22:71-84
Hilton AJ, Jenkinson P, Hollins TW, Parry DW (1999) Relationship between cultivar height and severity of Fusarium ear blight in wheat. Plant Pathol 48:202-208

Holzapfel J, Voss H-H, Miedaner T, Korzun V, Häberle J, Schweizer G, Mohler V, Zimmermann G, Hartl L (2008) Inheritance of resistance to Fusarium head blight in three European winter wheat populations. Theor Appl Genet 117:1119-1128

Ittu M, Saulescu NN, Hagima I, Ittu G, Mustatea P (2000) Association of Fusarium head blight resistance with gliadin loci in a winter wheat cross. Crop Sci 40:62-67

Jia GF, Chen PD, Qin GJ, Bai GH, Wang XE, Wang SL, Zhou B, Zhang SZ, Liu DJ (2005) QTLs for Fusarium head blight response in a wheat DH population of Wangshuibai/Alondra's. Euphytica 146:183-191

Kammholz SJ, Campbell AW, Sutherland MW, Hollamby GJ, Martin PJ, Eastwood RF, Barclay I, Wilson RE, Brennan PS, Sheppard JA (2001) Establishment and characterisation of wheat genetic mapping populations. Aust J Agric Res 52:1079-1088

Khatibi PA, Berger G, Liu SY, Brooks WS, Griffey CA, Schmale DG (2012) Resistance to Fusarium head blight and deoxynivalenol accumulation in Virginia barley. Plant Dis 96:279-284

Klahr A, Zimmermann G, Wenzel G, Mohler V (2007) Effects of environment, disease progress, plant height and heading date on the detection of QTLs for resistance to Fusarium head blight in an European winter wheat cross. Euphytica 154:17-28

Knopf C, Becker H, Ebmeyer E, Korzun V (2008) Occurrence of three dwarfing Rht genes in German winter wheat cultivars. Cereal Res Commun 36:553-560

Kosambi DD (1944) The estimation of map distance from recombination values. Ann Eugenic 12(3):172-175

Kumar N, Kulwal PL, Balyan HS, Gupta PK (2007) QTL mapping for yield and yield contributing traits in two mapping populations of bread wheat. Mol Breed 19:163-177

Lafever HN (1988) Registration of becker wheat. Crop Sci 28:376

Lander ES, Green P, Abrahamson J, Barlow A, Daly MJ, Lincoln SE, Newburg L (1987) MAPMAKER: an interactive computer package for constructing primary genetic linkage maps of experimental and natural populations. Genomics 1:174-181

Lin F, Xue SL, Zhang ZZ, Zhang CQ, Kong ZX, Yao GQ, Tian DG, Zhu HL, Li CJ, Cao Y, Wei JB, Luo QY, Ma ZQ (2006) Mapping QTL associated with resistance to Fusarium head blight in the Nanda 2419 and Wangshuibai population: II: type I resistance. Theor Appl Genet 112:528-535

Liu S, Abate ZA, McKendry AL (2005) Inheritance of Fusarium head blight resistance in the soft red winter wheat Ernie. Theor Appl Genet 110:454-461

Liu S, Abate ZA, Lu H, Musket T, Davis GL, McKendry AL (2007) QTL associated with Fusarium head blight resistance in the soft red winter wheat Ernie. Theor Appl Genet 115:417-427

Liu S, Hall MD, Griffey CA, McKendry AL (2009) Meta-analysis of QTL associated with Fusarium head blight resistance in wheat. Crop Sci 49:1955-1968

Liu SY, Griffey CA, Hall MD, Chen J, Liu S, Tucker D, Brooks WS (2012a) Registration of Becker/Massey wheat recombinant inbred line mapping population. J Plant Reg 6:358-362

Liu SY, Christopher MD, Griffey CA, Hall MD, Gundrum PG, Brooks WS (2012b) Molecular characterization of resistance to Fusarium head blight in US soft red winter wheat breeding line VA00 W-38. Crop Sci 52:2283-2292

Loffler M, Schon CC, Miedaner T (2009) Revealing the genetic architecture of FHB resistance in hexaploid wheat (Triticum aestivum L.) by QTL meta-analysis. Mol Breed 23:473-488

Malla S, Ibrahim AMH, Yen Y, Berzonsky WA, Stein J (2010) QTL analysis of Novel FHB resistance in SD97060. Intern J Plant Breed 4:47-54 
Martin RA, Johnston HW (1982) Effects and control of Fusarium diseases of cereal grains in the atlantic provinces. Can J Plant Pathol 4:210-216

McKendry AL, Berg JE, Tague DN, Kephart KD (1995) Registration of 'Ernie' wheat. Crop Sci 35:1513

McKendry AL, Tague DN, Wright RL, Tremain JA, Conley SP (2005) Registration of 'Truman' wheat. Crop Sci 45:421-423

McKendry AL, Tague DN, Wright RL, Tremain JA (2007) Registration of 'Bess' wheat. J Plant Reg 1:21-23

Mesterhazy A (1995) Types and components of resistance to Fusarium head blight of wheat. Plant Breed 114:377-386

Murphy CF (1967) Registration of blue boy wheat. Crop Sci 7:82

Paillard S, Schnurbusch T, Tiwari R, Messmer M, Winzeler M, Keller B, Schachermayr G (2004) QTL analysis of resistance to Fusarium head blight in swiss winter wheat (Triticum aestivum L.). Theor Appl Genet 109:323-332

SAS Institute Inc. (2008) SAS/STAT user's guide. Version 9.2, Cary, $\mathrm{NC}$

Schmolke M, Zimmermann G, Buerstmayr H, Schweizer G, Miedaner T, Korzun V, Ebmeyer E, Hartl L (2005) Molecular mapping of Fusarium head blight resistance in the winter wheat population Dream/Lynx. Theor Appl Genet 111:747-756

Schmolke M, Zimmermann G, Schweizer G, Miedaner T, Korzun V, Ebmeyer E, Hartl L (2008) Molecular mapping of quantitative trait loci for field resistance to Fusarium head blight in a European winter wheat population. Plant Breed 127:459-464

Semagn K, Bjrnstad A, Skinnes H, Mary AG, Tarkegne Y, William M (2006) Distribution of DArT, AFLP and SSR markers in a genetic linkage map of a double haploid hexaploid wheat population. Genome 49:545-555

Semagn K, Skinnes H, Bjørnstad Å, Marøy AG, Tarkegne Y (2007) Quantitative trait loci controlling Fusarium head blight resistance and low deoxynivalenol content in hexaploid wheat population from 'Arina' to NK93604. Crop Sci 47:294-303

Shen XR, Ittu M, Ohm HW (2003) Quantitative trait loci conditioning resistance to Fusarium head blight in wheat line F201R. Crop Sci 43:850-857

Somers DJ, Fedak G, Savard M (2003) Molecular mapping of novel genes controlling Fusarium head blight resistance and deoxynivalenol accumulation in spring wheat. Genome 46:555-564

Somers D, Isaac P, Edwards K (2004) A high-density microsatellite consensus map for bread wheat (Triticum aestivum L.). Theor Appl Genet 109:1105-1114

Song QJ, Shi JR, Singh S, Fickus EW, Costa JM, Lewis J, Gill BS, Ward R, Cregan PB (2005) Development and mapping of microsatellite (SSR) markers in wheat. Theor Appl Genet 110:550-560

Sourdille P, Singh S, Cadalen T, Brown-Guedira G, Gay G, Qi L, Gill B, Dufour P, Murigneux A, Bernard M (2004) Microsatellite-based deletion bin system for the establishment of genetic-physical map relationships in wheat (Triticum aestivum L.). Funct Integr Genomic 4:12-25

Srinivasachary, Gosman N, Steed A, Simmonds J, Leverington-Waite M, Wang Y, Snape J, Nicholson P (2008) Susceptibility to Fusarium head blight is associated with the Rht-D1b semi-dwarfing allele in wheat. Theor Appl Genet 116:1145-1153

Srinivasachary NG, Steed A, Hollins TW, Bayles R, Jennings P, Nicholson P (2009) Semi-dwarfing Rht-B1 and Rht-Dl loci of wheat differ significantly in their influence on resistance to Fusarium head blight. Theor Appl Genet 118:695-702

Starling TM, Roane CW, Camper HM (1984) Registration of Massey wheat. Crop Sci 24:1000

Tacke BK, Casper HH (1996) Determination of deoxynivalenol in wheat, barley, and malt by column clean up and gas chromatography with electron capture detection. J AOAC Int 79:472-475

Van Ooijen JW, Voorrips RE (2001) JoinMap ${ }^{\circledR}$ 3.0. Software for the calculation of genetic linkage maps. Plant Research International, Wageningen, The Netherlands

Voorrips RE (2002) MapChart: Software for the Graphical Presentation of Linkage Maps and QTLs. J Heredity 93:77-78

Voss HH, Holzapfel J, Hartl L, Korzun V, Rabenstein F, Ebmeyer E, Coester H, Kempf H, Miedaner T (2008) Effect of the Rht-D1 dwarfing locus on Fusarium head blight rating in three segregating populations of winter wheat. Plant Breed 127:333-339

Wang S, Basten CJ, Zeng ZB (2010) Windows QTL Cartographer 2.5. Department of Statistics, North Carolina State University, Raleigh http://statgen.ncsu.edu/qtlcart/WQTLCart.htm

Wilkinson PA, Winfield MO, Barker GLA, Allen AM, Burridge A, Coghill JA, Burridge A, Edwards KJ (2012) CerealsDB 2.0: an integrated resource for plant breeders and scientists. BMC Bioinforma 13:219

Yang ZP, Gilbert J, Fedak G, Somers DJ (2005) Genetic characterization of QTL associated with resistance to Fusarium head blight in a doubled-haploid spring wheat population. Genome 48:187-196

Yang J, Hu C, Hu H, Yu R, Xia Z, Ye X, Zhu J (2008) QTLNetwork: mapping and visualizing genetic architecture of complex traits in experimental populations. Bioinformatics 24:721-723

Yu JB, Bai GH, Zhou WC, Dong YH, Kolb FL (2008) Quantitative trait loci for Fusarium head blight resistance in a recombinant inbred population of Wangshuibai/Wheaton. Phytopathology 98:87-94

Zhou W, Kolb FL, Bai G, Shaner G, Domier LL (2002) Genetic analysis of scab resistance QTL in wheat with microsatellite and AFLP markers. Genome 45:719-27

Zhou WC, Kolb FL, Yu JB, Bai GH, Boze LK, Domier LL (2004) Molecular characterization of Fusarium head blight resistance in Wangshuibai with simple sequence repeat and amplified fragment length polymorphism markers. Genome 47:1137-1143 